Arab Univ. J. Agric. Sci., Ain Shams Univ., Cairo, Egypt

28(1), 131-139, 2020

Website: http://ajs.journals.ekb.eg

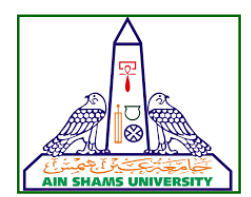

131

\title{
EFFICIENCY IMPACT OF CHICKEN MANURE AND ITS TEA UNDER CHEMICAL NPK FERTILIZERS REGIME ON YIELD AND QUALITY OF MOLOKHIA (JEW'S MELLOW)
}

\author{
Amal K. Abou El-Goud* \\ Botany Dept. (Organic Agriculture), Fac. of Agric., Damietta Univ., Damietta, Egypt \\ *Corresponding author: amalgoud08@gmail.com
}

Received 11 February, 2020

Accepted 18 May, 2020

\section{ABSTRACT}

Two field experiments were conducted to assess chicken manure (Ch.M.) and its tea on quantity and quality yield of Molokhia (Jew's mellow) plant during two summer seasons of 2017 and 2018 in Fac. of Agric. El-Shatby, Alexandria University. This investigate aimed to compare between chicken manure (Ch.M.R ${ }_{100 \%}$ and $\mathrm{R}_{50 \%}$ ), chicken manure tea $\left(R_{100 \%}\right.$ and $\left.R_{50 \%}\right)$ and the mixture of them (R50\% of Ch.M. + R50\% of its tea) under four levels (NPKo $\%, \mathrm{NPK}_{30 \%}, \mathrm{NPK}_{60 \%}$ and $\mathrm{NPK}_{100 \%}$ ) of chemical fertilizers. Every experiment was carried out with 13 treatments in a randomized complete block design (RCBD) with three replicates (total plot area $=2 \& 1=2 \mathrm{~m}^{2}$ ). The results indicated that, chicken manure tea $100 \%+30 \%$ NPK(T6) gave the highest mean values of vegetative growth i.e. plant height $(92.0 \mathrm{~cm})$, number of leaves/plant (29.5), leaf length $(13.87 \mathrm{~cm})$, increases in vitamin C. $(110.77 \mathrm{mg} / \mathrm{g} \mathrm{F.W.}$ ) and dry weight of leaves $(10.25 \mathrm{~g})$ as an average of both seasons. While the mixture of "chicken manure $50 \%$ and chicken manure tea $50 \% "+30 \%$ NPK (T10) lead to significant increases in fresh leave weight (49.84 $\mathrm{g} /$ plant) and total yield of fresh leaves $(4.7 \mathrm{~kg} / \mathrm{plot}$ ) as an average of both seasons. Highest increases in $\mathrm{P}$ uptake $(1.37 \mathrm{mg} / \mathrm{g})$ and $\mathrm{K}$ uptake $(20.27 \mathrm{mg} / \mathrm{g})$ either chicken manure $100 \%$ (T1) or the mixture of "chicken manure $50 \%$ and chicken manure tea 50 \%" T9, respectively. The maximum N uptake (2.79 $\mathrm{mg} / \mathrm{g}$ ), total chlorophyll in leaves (47.44 SPAD) and leave width $(6.82 \mathrm{~cm})$ as an average of both seasons by the mixture of "chicken manure $50 \%$ and chicken manure tea $50 \%$ " + $100 \%$ NPK (T12) compared with the control once. Organic plants "safe food" produced with organic fertilizers and their teas really supply more nutrients and vitamins
\end{abstract}

"chemical free" and health protective so used sustainably in food and environmental friendly.

Keywords: Chicken manure, its tea, Molokhia, Yield and quality

\section{INTRODUCTION}

Molokhia (Jew's mellow) belongs to the family Tiliacea (Khan et al 2015). It is a popular tropical leafy vegetable crop in Africa, Asia, some parts of the Middle East, Sudan, Kenya, Zimbabwe, Nigeria and Latin America (Odofin et al 2011; Naim et al 2015 and Garjila et al 2017). Jew's mellow is known as the golden fiber and used as mucilaginous vegetable. Fresh leaves and powder drying are used to prepare a smiling sticky sauce, which is the main economic product of vegetable. Leaves are rich in beta carotene, niacin, riboflavin, iron, calcium, phosphorous and vitamins $\mathrm{C}$ and $\mathrm{E}$, antioxidant activity, \& tecopherol, protein and high dry matter (Garjila et al 2017). Jew's mellow is cultivated in range between 2.5 -3.2 million tons; about $30-60 \%$ of world is grown them in India and Bangladesh respectively (FAO, 2018). Fresh vegetables are important components of a healthy and balanced diet. Consumer's interest in the quality of vegetable products has increased worldwide (FAO, 2017 and 2018).

Chicken manure tea is rapidly growing and the concerns over the pesticides residues in food and can provide nutrients instantly to the plant much like the chemical fertilizers (Jigme et al 2015 and Cayci et al 2017). It is highly concentrated microbial solution produced by extracting beneficial microbies from chicken manure to increase microbial population densities during production 
(Izunobi, 2002; Javanmardi and Ghorbani, 2012 and Biratu et al 2018). It contains chelated micronutrients for easy plant absorption and the nutrients are in biologically available forms for both plants and microbial uptake (Adediran et al 2015; Law-Ogbomo and Osaigbovo, 2016).

Chicken manure is an important resource for soil amendment with the benefits of being environment-friendly and has been attributed to enhance the beneficial microbial communities in soil an improvement of mineral absorption conditions for plants and stimulation of defense compounds, growth regulators or phytohormones in plants (Javanmardi and Ghorbani, 2012). It helps to modify physical, chemical, and biological properties of the soil, provides slow release of nutrients and increases crop yield (Agbede et al 2008; Moral et al 2009). Composted organic manure especially from poultry wastes have been reported to improve mineral composition in tissues of vegetables such as Jew's mellow (Mazen et al 2010; Jonathan et al 2012). In contrast to the beneficial roles of compost, it could also be a potential source of contaminants depending on its origin. However, inorganic fertilizers have several limitations including high purchase costs, scarcity, pollution of ground water and deterioration of soil physical properties by depleting the soil organic matter on account of continuous usage over time (Ghoneim and El-Araby, 2003 and Adediran et al 2015 and Law-Ogbomo and Osaigbovo, 2016). Aim of this investigate to use the regime level of chemical NPK fertilizers with recommended doses of chicken manure and its tea to increase the quantity and quality of Molokhia (Jew's mellow).

\section{MATERIALS AND METHODS}

Two field experiments were carried out at the farm of Agricultural Faculty, El-Shattby, Alexandria University, at $20^{\text {th }}$ and $24^{\text {th }}$, July 2017 and 2018 , respectively to investigate the comparison effect response between chicken manure $R_{100 \%}$, its tea $\mathrm{R}_{\mathbf{1 0 0}}$ or Ch.M. $\mathrm{R}_{\mathbf{5 0} \%}+$ Ch.M. Tea $\mathrm{R}_{\mathbf{5 0} \%}$ under four levels $(0,30,60$ and $100 \%)$ of chemical NPK fertilizers on vegetative growth and yield quality of Molokhia (Jew's mellow) species c.v. Balady.

Soil texture was sandy $(39.12 \%)$ clay $(30.88 \%)$ silt $(30 \%)$; a surface soil sample $(0-30 \mathrm{~cm})$ was collected before planting and analyzed the physico-chemical characteristics during both seasons ( $\mathrm{pH}=8.4$, O.M. \%= 2.73\%, O.C. $\%=1,58 \%, \quad \mathrm{C} / \mathrm{N}$ ratio $=148: 1$, available of $\mathrm{N}=106.9 \mathrm{mg} / \mathrm{kg}, \mathrm{P}=48.3$ $\mathrm{mg} / \mathrm{kg}$ and $\mathrm{K}=1050 \mathrm{mg} / \mathrm{kg}$, E.C. (1:1 water extract) $=0.64 \mathrm{ds} / \mathrm{m}$ and $\mathrm{CaCO}_{3} \%=4.2 \%$ ).

Chicken manure tea was produced by soaked in tap water with volume $(1: 10)$ for two days and it sieved through a $2 \mathrm{~mm}$ sieve to produce its tea (Sundararasu and Jeyasankar, 2014 and Chaulain et al 2017).

Chick manure and chicken manure tea samples were taken before adding to the soil to determine (total organic matter\%= 12.5 and $14.3 \%$, organic carbon $\%=7.25$ and $7.34 \%, \mathrm{C} / \mathrm{N}$ ratio= $3.4: 1, \mathrm{pH}(1: 10)=7.6$ and 7.9 , E.C. $(1: 10$, water extract $)=5.0$ and $4.4 \mathrm{dS} / \mathrm{m}$, total amount of macro elements $; \mathrm{N}=2.14$ and $2.17 \%, \mathrm{P}=1.41$ and $1.42 \%$ and $\mathrm{K}=1.40$ and $1.43 \%$, respectively ) according to Chapman and Pratt, 1978; Evenhuis, 1978; Jackson, 1973; Page et al 1982 and Klute 1986.

The experiment was laid out in a randomized complete block design (RCBD) with three replicates, each replicate contained 13treatments. Total plot area was $(2.0 \mathrm{~m}$ length and $1.0 \mathrm{~m}$ width $=$ $2 \mathrm{~m}^{2}$ ) as experimental unit. Thirteen treatments can be illustrated as follows; $\mathrm{T} 1=$ Chicken manure $\mathrm{R}_{100 \%}$ (3.5 t/fed.), T2= Chicken manure $\mathrm{R}_{100 \%}+\mathrm{NPK}_{30 \%}$, $\mathrm{T} 3=$ Chicken manure $\mathrm{R}_{100 \%}+\mathrm{NPK}_{60} \%$, $\mathrm{T} 4=$ Chicken manure $\mathrm{R}_{100 \%}+\mathrm{NPK}_{100} \%, \mathrm{~T} 5=$ Chicken manure tea $R_{100 \%}\left(200 \mathrm{ml} / 1 \mathrm{~m}^{2}\right)$, T6= Chicken manure tea $\mathrm{R}_{100 \%}+\mathrm{NPK}_{30} \%, \mathrm{~T} 7=$ Chicken manure tea $\mathrm{R}_{100 \%}+\mathrm{NPK}_{60 \%}, \mathrm{~T} 8=$ Chicken manure tea $\mathrm{R}_{100 \%}+\mathrm{NPK}_{100 \%}, \mathrm{~T} 9=$ Chicken manure $\mathrm{R}_{50 \%+}$ chicken manure tea $\mathrm{R}_{50 \%}, \mathrm{~T} 10=$ Chicken manure $\mathrm{R}_{50 \%}+$ chicken manure tea $\mathrm{R}_{50 \%}+\mathrm{NPK}_{30 \%}, \mathrm{~T} 11=$ Chicken manure $\mathrm{R}_{50 \%}$ + chicken manure tea $\mathrm{R}_{50 \%}$ $+\mathrm{NPK}_{60} \%, \mathrm{~T} 12=$ Chicken manure $\mathrm{R}_{50 \%}+$ chicken manure tea $\mathrm{R}_{50 \%}+\mathrm{NPK}_{100 \%}$ and $\mathrm{T} 13=$ Control= $\mathrm{R}_{100 \%}$ of $\mathrm{N}$ (Ammonium Nitrate $33.5 \%$ ) $=300$ $\mathrm{kg} / \mathrm{fed}$. + P (Super Phosphate 15.5\%) $=150$ $\mathrm{kg} / \mathrm{fed}$. + K (Potassium Sulphate 48\%) $=75 \mathrm{~kg} / \mathrm{fed}$.

First cutting harvest of Molokhia "c.v. Balady" after 18 days from sowing and the end of both growing seasons, 2017 and 2018; randomized plants were taken from each experimental unit (plot) to determine growth parameters i.e. plant height $(\mathrm{cm})$, number of leaves/ plant, leave length (cm), leave width $(\mathrm{cm})$, leave dry weight (g/plant) were recorded at the end of the growing season and the total chlorophyll in leaves (SPAD) at a green stage (Roods and Blood-Worth,1964). The ascorbic acid "Vitamin C." (mg/100g fresh leaves weight) was determined by titration with 2,6 dichloro phenol-indo-phenol and calculated as ( $\mathrm{mg} / 100$ $\mathrm{ml}$ fresh juice). Samples of Molokhia leaves were washed by tap water then by distilled water and oven dried at $75^{\circ} \mathrm{C}$ for fixing dry weights (72h.) to 


\section{Efficiency impact of chicken manure and its tea under chemical NPK fertilizers regime on yield and quality of Molokhia (Jew's mellow)}

determine some chemical components (NPK uptakes in leaves) after dryness leaves samples were milled and stored for analysis. Dried samples of leaves were finely ground, then wet digested by using concentrate of $\mathrm{H}_{2} \mathrm{SO}_{4} / \mathrm{H}_{2} \mathrm{O}_{2}$ according to Lowther, 1980 to determine the percentage of phosphorus (vanaomoly-bdophosphoric method), potassium (flam photometer) according to Jackson, 1973. Total nitrogen was determined by Nessler's method (Chapman and Pratt, 1978) in leaves. Fresh leaves yield (g/plant) and total yield of fresh leaves ( $\mathrm{kg} / \mathrm{plot} / \mathrm{season})$ were determined at the end of seasons, 2017 and 2018.

All data were statistically analyzed using the SAS program (SAS, 2001) and means of seven treatments were compared using Duncan's Multiple Range test at $5 \%$ level of probability in this investigation.

\section{RESULTS AND DISCUSSIONS}

\section{A) Vegetative growth and yield characters}

Molokhia species "c.v. Balady"; the first harvesting stage 18 days after sowing and the second harvest was after two weeks. The means in Table 1 and 2, the different treatments showed significant response on growth characters during both the seasons (2017 and 2018). Data showed that the recommended dose of chicken manure tea and NPK ${ }_{\text {R30 }} \%$ of chemical fertilizers (T6) lead to significant increases in plant height $(92.0 \mathrm{~cm})$, number of leaves /plant (26.67 and 32.33), leave length (12.8 and $14.93 \mathrm{~cm}$ ) and leave dry weight (9.93 and $10.57 \mathrm{~g}$ ) for both seasons as compared to control NPK R100\% treatment (Table 1 and 2). The highest significant increases in leave width $(6.5$ and 7.13 $\mathrm{cm}$ ) and total chlorophyll in leaves (45.77 and 49.10 SPAD) at $\mathrm{T} 12=$ Chicken manure $\mathrm{R}_{50 \%}+$ chicken manure tea $\mathrm{R}_{50 \%}+\mathrm{NPK}_{100} \%$ more than controlled plant. There are not significant differences between T6 and T12 and between T12, T10 and T9 in leave length $\mathrm{cm}$ and total cholorophyll in leaves, respectively in first season (Table 1). Total yield of fresh leaves were highly significant increases (4.67 and $4.69 \mathrm{~kg} / \mathrm{plot}$ ) and fresh leave yield (46.67 and $53.0 \mathrm{~g} / \mathrm{plant}$ ) at $\mathrm{T} 10=$ Chicken manure $\mathrm{R}_{50 \%}$ + chicken manure tea $\mathrm{R}_{50 \%}+\mathrm{NPK}_{30} \%$ in both seasons, Table (1). This investigation revealed $\mathrm{T} 6=$ Chicken manure tea $\mathrm{R}_{100 \%}+\mathrm{NPK}_{\mathbf{3}} \%$ or $\mathrm{T} 10=$ Chicken manure $\mathrm{R}_{50 \%}+$ chicken manure tea $\mathrm{R}_{50 \%}+\mathrm{NPK}_{30} \%$, lead to high significantly increases in the vegetative growth and total yield characters in both seasons in Table (1 and 2). Singh and Hussain, 2015, prepared and reported that, chicken manure contains highly significant quantities of nutrients, beneficial microbes biologically active metabolites, cytokines, auxins, gibberellins and group B vitamins, so as to get better healthy food and quality of diverse plants. The combined application of poultry and inorganic fertilizers has been shown to integrate the attributes of organic and inorganic fertilizers. Jonathan et al (2012) observed that the Jews planted on $100 \%$ compost manure had the best growth followed by $50 \%, 30 \%$ and $0 \%$ compost manure respectively (in terms of plant height, leaf number, stem girth, and leaf area). Significantly higher growth parameters obtained in plants treated with NPK fertilizer in comparison to those treated with sole poultry manure during the initial stage of study could be attributed to the ready availability of nutrients in contrary to the slow release of nutrients through the decomposition of poultry manure as reported by Khan et al 2015. Significantly higher growth parameters obtained in poultry manure treatments when compared to NPK 15:15:15 at 56 days after planting could be due to the fact that the nitrogen present in poultry manure is released slowly and consistently to meet the growth requirements of plant growth stages unlike inorganic nitrogen source that is easily lost soon after application (Kareem and Douglas, 2014 and Adediran et al 2015). The plants that received $20 \mathrm{t} /$ ha of chicken manure had the highest height while plants in the control which were grown without chicken manure had the lowest plant height at all growth occasions. The result is in tandem with Adediran et al 2015 and Cayci et al 2017 in a study on the effect of organic and inorganic fertilizer on the growth and yield of Corchorus olitorius. Similar results were obtained by Khan et al (2015) in a study on the effect of chicken manure and commercial fertilizer on performance of Corchorus olitorious. This is in harmony with the findings and reports of many researchers. Ndlovu and Afolayan (2008) who reported increased plant height resulting from application of high rate of chicken manure and the lowest number of leaves was obtained from Jew's mallow plants which did not receive chicken manure fertilizer. This could be attributed to the fact that $20 \mathrm{t} / \mathrm{ha}$ was compatible with the requirements and growing characteristics and yield enhancement. Ndlovu and Afolayan, 2008; who recommended that manure was applied at rates that are compatible with the nutrient requirements and increase yield with high plant biomass because of highly photosynthetic rate. 


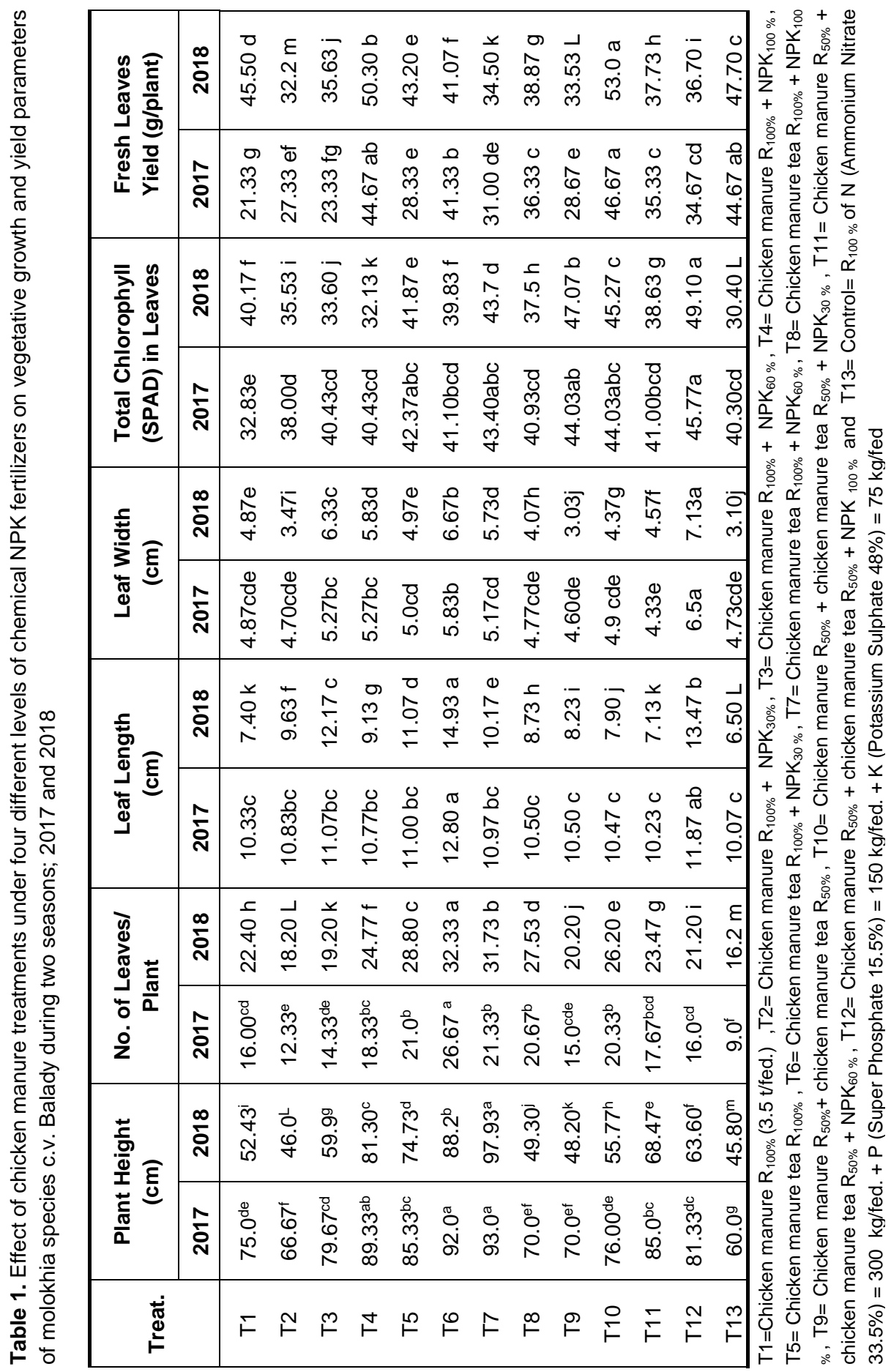



mellow)

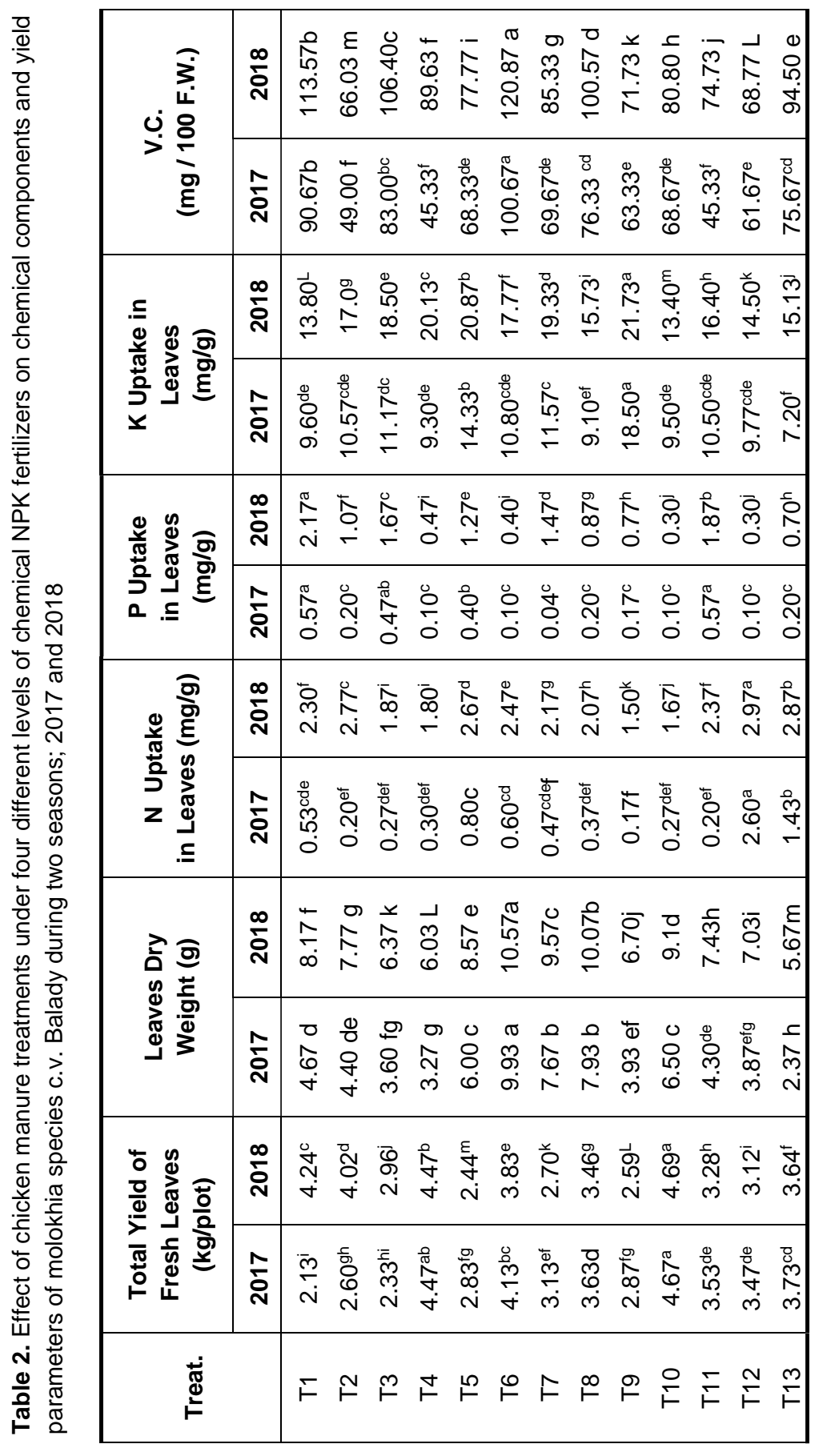

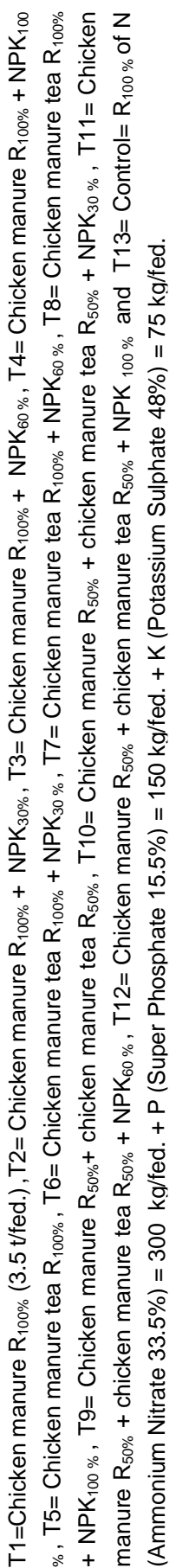


Marketable yield of Jew's mallow was significantly increased with the increment levels of chicken manure. This might be attributed to the stimulating effect of chicken manure that supplies plant with nutrients required for better yield. For application of chicken manure at different levels, the highest rates of chicken manure (10 and $20 \mathrm{t} / \mathrm{ha}$ ) gave a significantly substantial high yield, yield fresh and dry weight than other rates. These results are in good agreement with the findings of several researchers who revealed that organic manure increases the vegetative growth and biomass production effectively Rashwan, 2012; Nwagburuka et al 2012 and Law-Ogbomo and Osaigbovo, 2016. The contribution of compost amendment to higher growth and yield of Corchorus compared to control soil without amendment was a reflection of the beneficial roles played by the compost amendment in enhancing crop yield (Agbede et al 2008).

\section{B) Total yield and chemical components of} Molokhia leaves

According to the results (Table 2) of variance analysis, in order to determine impact the high rate of chicken manure and chicken manure tea under the lowest level of mineral NPK fertilizers on the healthy growth and quality molokhia plant. Data presented in Table 2, showed that the highest significant means of $\mathrm{N}, \mathrm{P}$ and $\mathrm{K}$ uptake in leaves were (2.9, 2.17 and $21.73 \mathrm{mg} / \mathrm{kg})$ at T1 " Chicken manure $\mathrm{R}_{100 \%}$ " and T9 "Chicken manure $\mathrm{R}_{50 \%}+$ chicken manure tea $\mathrm{R}_{50 \%}$, respectively in both seasons more than other treatments. Results in Table 2, were reported that the highly significant increases in V.C. (100.67 and $120.87 \mathrm{mg} / \mathrm{g}$ ) in fresh leaves and leaves dry weight (9.93 and 10.57 g) at the treatment T6=" Chicken manure tea R100\%+NPK30\%". But T10 = "Chicken manure $\mathrm{R} 50 \%$ + chicken manure tea R50\% + NPK30\%" lead to a significant increase in total yield of fresh leaves (4.69 and $4.67 \mathrm{~kg} / \mathrm{plot}$ ) of both seasons (Table 2). These results can be explained that chicken manure and its tea are rich in macro $(N, P$ and $\mathrm{K}$ ) and micronutrients, enhance soil microflora and healthy plant growth, which lead to increase contain essential elements, vitamins and quality food (Chaulagain et al 2017 and Al Ali et al 2019). Data in Table 2 and 1 cleared that, there are significant differences between thirteen treatments in vegetation growth, yield components parameters and total fresh yield. In the same trend
Garjila et al 2017, gave that organic manure of poultry manure, which having superior growth, improved all parameters of Jew's mallow. So that the highest yield at organic fertilizers and the lowest total yield at chemical fertilizers. In the same trend, (Tovihoudji et al 1997; Javanmardi and Ghorbani, 2012; Adediran et al 2015 and Jigme et al 2015) fined that, use of chicken manure improves maro and micronutrients, the soil aggregates, water holding capacity, bulk density, microbial properties (enzymes and microbial population) and organic matter, which reflected on enhancement in early and latter stages of plant growth and applied them must be got for optimum yield and quality products.

\section{CONCLUSION}

Effective response on vegetation parameters, total yield of fresh leaves and quality of molokhia "C.V. Balady" improved with addition of T1"chicken manure R ${ }_{100 \%}$ ",T6 " chicken manure tea $\mathrm{R} 100 \%+\mathrm{NPK}_{30 \%}$ ", T9 "the mixture of chicken manure $R{ }_{50 \%}$ and chicken manure tea $R{ }_{50 \%}$ ", or T10 "the mixture of chicken manure $\mathrm{R}{ }_{50 \%}$ and chicken manure tea $\mathrm{R}{ }_{50} \%+\mathrm{NPK}{ }_{30 \%}$ "as compared to the huge chemical fertilizers \& pesticides.

\section{Future prospective}

Further this investigation intends to clean environment from differ chemicals pollution hazard. Decrease able of chemical fertilizers for the lowest rate and increase amounts of differ organic fertilizers and their teas were acted as an environmental friend, quality soil, safety food and human health.

\section{REFERNCES}

Al Ali M., Gencoglan C. and Gencoglan S. 2019. The effect of organic and inorganic fertilizer applications on yield and plant vegetative growth of eggplant (Solanum melongena, L.). Int. J. of Plant \& Soil Sci. 29, 1-9.

Agbede T.M., Ojeniyi S.O. and Adeyemo A.J. 2008. Effect of poultry manure on soil physical and chemical properties, growth and grain yield of sorghum in South-West, Nigeria. Am. Eurasian. J. Sust. Agric., 2, 72-77.

Biratu G.K., Elias E., Ntawuruhunga Ph. and Nhamo N. 2018. Effect of chicken manure application on cassava biomass and root yields in two agro-ecologies of Zambia. Agriculture MDPI, 8, 1-15. 


\section{Efficiency impact of chicken manure and its tea under chemical NPK fertilizers regime on yield and quality of Molokhia (Jew's mellow)}

Cayci G., Temiz C. and Ok S.S. 2017. The effects of fresh and composted chicken manures on some soil characteristics. Communications in Soil Science and Plant Analysis, 22(10), 15281538.

Chaulagain A., Dhurva P., Lamichhane G.J. 2017. Vermicompost and its role in plant growth promotion. Int. J. of Res., 4(8), 849864.

Chapman H.D. and Pratt P.F. 1978. Methods of Analysis for Soil Plant and Waters. Univ. of California, Div. Agric. Sci., 309 p.

Evenhuis B. 1978. Nitrogen determination. Dept. Agric. Res. Royal tropical inst. Amesterdam.

FAO, 2017. The future of food and agriculture. Trends and challenge. Available at: http://www.fao.org/3/a-i6583e.pdf (23-01-2019).

FAO, 2018. Future Fibers. Jute. Available at: http://www.fao.org/economic/futurefibres/fibres/ Jute/en/ (22-20-2018)

Garjila Y.A., Shiyam J.O. and Augustine Y. 2017. Response of Jew's Mallow (Corchorus olitorius L.) to Organic Manures in the Southern Guinea Savanna Agroecological Zone of Nigeria. Asian Res. J. Agric., 3(1), 1-6.

Ghoneim I.M. and El-Araby S.M. 2003. Effect of organic manure source and biofertilizer type on growth, productivity and chemical composition of jew's mallow (Corchorus olitorious L.). Plants J. Agric. \& Env. Sci., 2(2), 88-105.

Izunobi N.D. 2002. Poultry Husbandry: An Integrated Approach for Tertiary Students, Extension Agents, Policy Makers and Farmers. Mgbe-Bpp Publishing House, Ihiala.

Jigme N.J., Sutigoolabud P., Inthasan J. and Sakhonwasee S. 2015. The effect of organic fertilizers on growth and yield of broccoli (Brassica oleracea, L.). J. of Organic Systems, 10(1), 9-14.

Javanmardi J. and Ghorbani E. 2012. Effects of chicken manure and vermicompost teas on herb yield, secondary metabolites and antioxidant activity of lemon basil. Adv. Hort. Sci., 26(3-4), 151-157.

Jackson M.L. 1973. Soil Chemical Analysis. Constable and Co. LTD. London.

Jonathan S.G, Oyetunji O.J., Olawuyi O.J. and Asemoloye M.D. 2012. Growth responses of Corchorus olitorius Lin. (Jute) to the application of organic manure as an organic fertilizer. Academia Arena, 4(9), 48-56.

Klute, A. 1986. Methods of Soil Analysis Part 1, $2^{\text {nd }}$ ed., Agron. Monor. GASA and SSSA, Madison, $\mathrm{W}$.
Kareem A.M. and Douglas A.I. 2014. Effect of organic and inorganic fertilizer on the yield and Nutrient composition of jute mallow. Global J. Agric. Res., 2(3), 1-9.

Khan M.A., Rahaman M.S., Al-Jubayer A. and Islam J.M. 2015. Modification of Jute Fibers by Radiation-Induced Graft Copolymerization and their Applications: Cellulose-based Graft Copolymers: Structure and chemistry. Edition: 1st, Chapter: 11, Publisher: CRC Press 2015, Editors: Vijay Kumar Thakur, pp. 209-234.

Law-Ogbomo K.E. and Osaigbovo A.U. 2016. Growth and yield of ewedu (Corchorus olitorius) as influenced by food waste compost and inorganic fertilizer in a humid ultisol of southwestern Nigeria. Nigerian J. Agric., Food \& Environ., 12(1), 80-84.

Lowther G.R. 1980. Use of a single $\mathrm{H}_{2} \mathrm{SO}_{4}-\mathrm{H}_{2} \mathrm{O}_{2}$ digest for the analysis of Pinus radiate needles. Common Soil Sci. Plant Analysis, 11, 175188.

Mazen A., Faheed F.A. and Ahmed A.F. 2010. Study of potential impacts of using organic manure in the amendment of desert reclaimed soil on wheat and Jews mallow plants. Braz Arch. Biol. Technol., 53(4), 917-930.

Moral R., Paredes C., Bustamante M.A., Marhuenda-Egea F. and Bernal M.P. 2009. Utilization of manure composts by high-value crops: safety and environmental challenges. Bioresour Technol., 100(22), 5454-5460.

Naim A.H., Kawthar M. Ahmed and Ahmed F.E. 2015. Effects of chicken manure on growth and yield of jute mallow (Corchorus olitorius L.). Library J., doi:10.4236/oalib.1102042, Vol. 2/e2042.

Ndlovu J. and Afolayan A.J. 2008. Nutritional analysis of the South African wild vegetable Corchorus olitorius (L.). Asian J. Plant Sci., 7(6), 615-618.

Nwagburuka C.C., Olawuyi O.J., Oyekale K.O., Ogunwenmo K.O., Denton O.A. and Nwankwo E. 2012. Growth and yield response of Corchorus olitorius (L.) in the treatment of Arbuscular mycorrhza (AM), poultry manure (PM), combination of AM-PM and inorganic fertilizer (NPK). Adv. Appli. Sci. Res., 3(3), 1466-1471.

Odofin A.J., Oladiran J.A., Oladipo J.A. and Wuya E.P. 2011. Determination of evapotranspiration and crop coefficients for bush okra (Corchorus olitorius) in a sub-humid area of Nigeria. Afri. J. Agric. Res., 6(17), 39493953. 
Sparks D.L., Page A.L., Helmke P.A. Loeppert R.H., Soltanpour P.N. Tabatabai M.A., Johnston C.T. and Sumner M.E. 1996. Methods of soil analysis. Part 3. Published by Soil Sci. Society of America, Inc. American Society of Agronomy, Inc. Madison, Wisconisn, USA, pp. 93-553.

Rashwan A.M.A. 2011. Effect of sowing dates and plant spacing on growth and yield of some Jew's mallow ecotypess (Corchorus olitorius L.) under South Valley condition. Assiut J. Agric. Sci., 42(2), 391-413.

Roods F.M. and Blood-Worth M.E. 1964. Area measurement of cotton leaf by dry weight method, Agronomy J., 56(5), 520-525.
Sundararasu K. and Jeyasankar A. 2014. Effect of vermiwash on growth and yield of brinjal (Solanum melongena, L.). Asian J. of Sci. and Tech., 5(3), 171-173.

Singh C.A. and Hussain A. 2015. Effect of vermicompost on growth, yield and quality of vegetable crops. Int. J. of Applied and Pure Sci. and Agri., 1(8), 49-56.

SAS Inst. Inc. 2001. Statistical Analysis Software ${ }^{\circledR}$. Cary, in. NC: SAS Institute Inc. USA.

Tovihoudji G.P., Paul D.C., Irénikatché A.P.B., Esaie, Emile A.C. and Gustava D.D. 1997. Response of jute mallow (Corchorus olitorius L.) to organic manure and inorganic fertilizer on a ferruginous soil in North-eastern Benin. J. Appl. Biosci., pp. 8610-8619. 
مجلة اتحاد الجامعات العربية للعلوم الزراعية، جامعة عين شمس، القاهرة، مصر مجلد(28)، عدد(1)، 139-131، 2020

Website: http://ajs.journals.ekb.eg

\title{
تأثير كفاءة سبلة الكتكوت وشاي السبلة تحت مستويات منخفضة من التسميد الكيماوي على إنتاج وجودة الملوخية
}

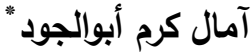 \\ قسم النبات الزراعي (الزراعة العضوية) - كلية الزراعة - جامعة دمياط - دمياط - مصر
}

*Corresponding author: amalgoud08@gmail.com

+ 50 5 من شاي السبلة+ 30\% من مخلوط الاسمدة الكيماوية NPK

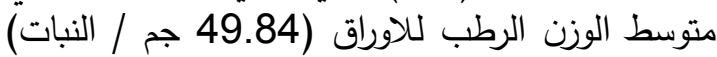

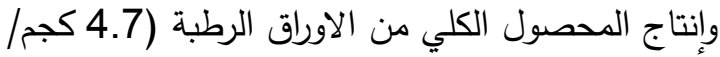

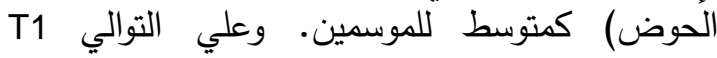
(100 من الجرعة الموصي بها من سبلة الكتكوت) وT10 (المخلوط من 50\% من من الجرعة الموصي بهاب

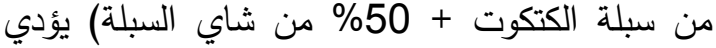

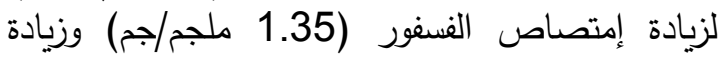

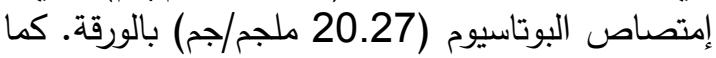

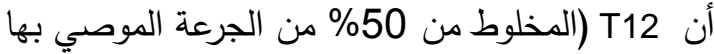

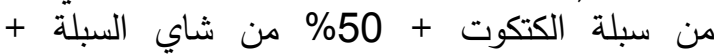
100 10 من NPK أدي لزيادة إمتصاص النيتروجين

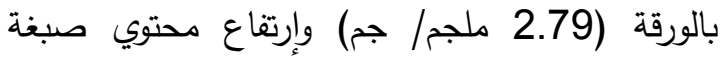

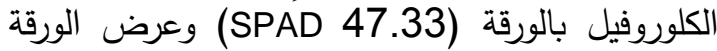
(6.82 سم) كمتوسط للموسمين مقارنة بإستخدام

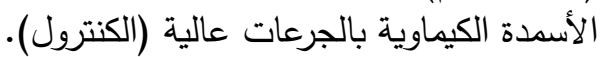

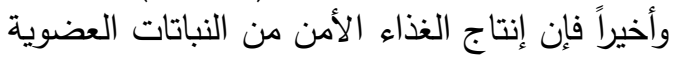

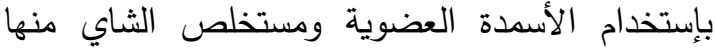
لإمداد النباتات بالعديد من العنات العناصر الغذائية

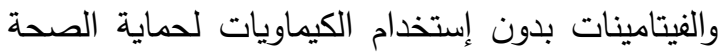
وهو الإستخدام الأمثل لإنتاج الغذاء الآمن والصديق الكيقات الصنات

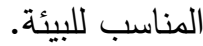

الكلمات المفتاحية: الملوخية، سبلة الكتكوت، شاى السبلة

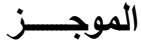

تم عمل تجربتين حقليتين بكلية الزراعة- قسم خضر (الثاطبي)- جامعة الأسكندرية لدراسة تأثير

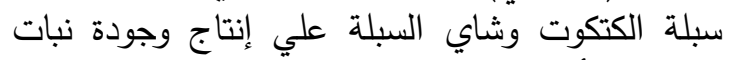

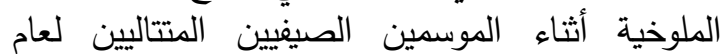

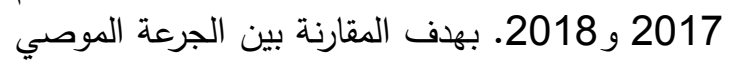

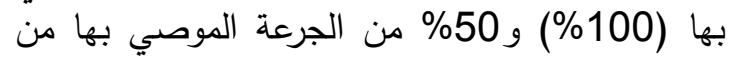

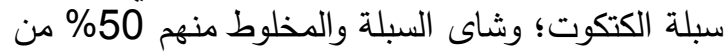
سبلة الكتكوت + 50\% من شاي السبلة بإستخدام أربع

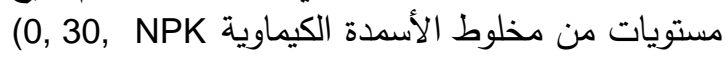

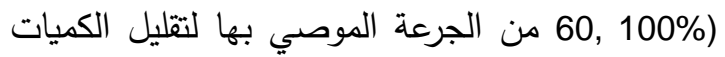
المستخدمة منها في ظل وجود التسميد العضوي. تحتوي كل تجربة على 13 معاملة و 3 مكررات للمعاملة وتحلل إحصائيا بنظام القطاعات الحبات العشوائية المتكاملة ومساحة الحوض وتهل (الوحدة التجريبية)= 2 متر

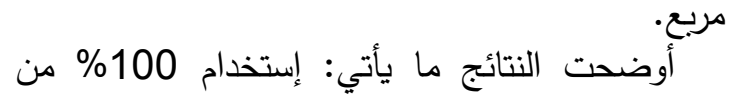

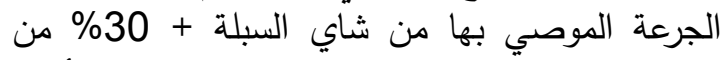

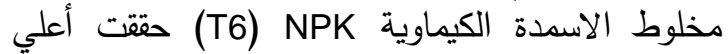
النتائج في الإنتاج والجودة (متوسط طول الإيمات النبات 92

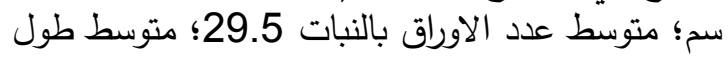

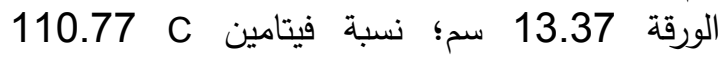
ملجم/جم وزن رطب ومتوسط الوزن الجاف للافئ لاوراق

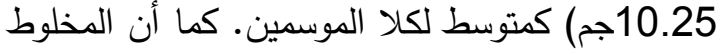

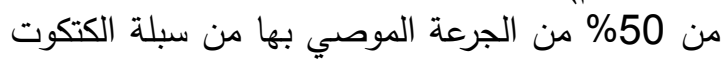
ا.د علاء الدين محمد طنطاوي 